\title{
Article
}

\section{Forced Marriage, Coercive Control, and Conducive Contexts: The Experiences of Women in Scotland}

Chantler, Khatidja and McCarry, Melanie

Available at http://clok.uclan.ac.uk/24166/

Chantler, Khatidja ORCID: 0000-0001-9129-2560 and McCarry, Melanie (2020) Forced Marriage, Coercive Control, and Conducive Contexts: The Experiences of Women in Scotland. Violence Against Women, 26 (1). pp. 89-109. ISSN $1077-8012$

It is advisable to refer to the publisher's version if you intend to cite from the work. http://dx.doi.org/10.1177/1077801219830234

For more information about UCLan's research in this area go to http://www.uclan.ac.uk/researchgroups/ and search for <name of research Group>.

For information about Research generally at UCLan please go to http://www.uclan.ac.uk/research/

All outputs in CLoK are protected by Intellectual Property Rights law, including Copyright law. Copyright, IPR and Moral Rights for the works on this site are retained by the individual authors and/or other copyright owners. Terms and conditions for use of this material are defined in the policies page.

\section{CLoK}

Central Lancashire online Knowledge www.clok.uclan.ac.uk

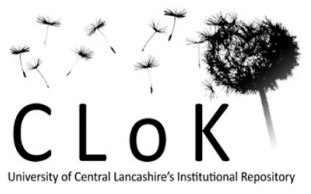




\title{
FORCED MARRIAGE, COERCIVE CONTROL AND CONDUCIVE CONTEXTS: THE EXPERIENCES OF WOMEN IN SCOTLAND
}

\author{
Authors \\ Dr Khatidja Chantler, School of Social Work, Care \& Community, University of Central \\ Lancashire, HA324, Harrington Building, Preston PR1 2 HE. \\ Tel: +44 1772892777 \\ Email: kchantler@uclan.ac.uk
}

Dr Melanie McCarry, School of Social Work and Social Policy, University of Strathclyde. Email: melanie.mccarry@strath.ac.uk

\section{AUTHORS' NOTE}

The authors are indebted to the women who participated in the study. This paper has equal joint authorship (50\% each author).

\section{FUNDING}

The Scottish Government funded the study, reference number SG/RES/2015/035.

\section{KEY WORDS}

Forced marriage, coercive control, conducive contexts, role of mothers 


\begin{abstract}
This paper is based on the first Scottish study of survivor perspectives of forced marriage. Indepth interviews were conducted with eight survivors. Our thematic analysis identified five key themes: understandings of forced marriage; the 'grooming' process; betrayal; legal responses and women's resistance. Utilising Stark's (2007) framework of coercive control and Kelly's (2007) concept of conducive contexts, we illuminate hitherto under-appreciated dynamics of forced marriage: i) the conceptualisation of forced marriage as a process rather than an event, ii) the role of mothers within patriarchal contexts and iii) betrayals of family and services as compounding long-term adverse effects of forced marriage.
\end{abstract}




\section{INTRODUCTION}

Forced marriage is widely recognised at a national and international level as a violation of women's and children's human rights and as a form of violence against women and children. Globally, forced and early marriage takes place in large numbers of countries in Africa, Asia and the Middle East. Forced Marriage has also been a feature of many orthodox religious communities and of 'shotgun' marriages in the West (Hester et al, 2007; Chantler and Gangoli

2011). In policy arenas, forced marriage is presented as distinct from arranged marriage. This is an important distinction, but it is also important to recognise the 'slippage' that can occur between arranged and forced marriage as discussed later (Gangoli et al, 2011). There is also an ongoing debate in the literature about forced marriage as a manifestation of honour-based violence (HBV) and whether HBV is a distinct form of violence or whether it can be subsumed under contemporary understandings of domestic abuse in Scotland and in the UK (Idriss, 2017; Aujla \& Gill, 2014). In this paper, we side-step these concerns as these debates are already well rehearsed and focus instead on theoretical resources which illuminate the processes of forced marriage and are centered on survivors' accounts. Key feminist authors draw attention to how researching lives from 'below' also simultaneously shed light on the operations of power by paying attention to the individual, their contexts and power relations within which their stories are embedded (Harding, 1991; Haraway, 2004; Hill-Collins 1990).

Forced marriage is widely recognised to be under-reported and therefore accurate information about the scale of the problem is difficult to determine (Home Office \& FCO, 2018). Natcen's (2009) research estimates that there are likely to be between 5000-8000 cases 
per annum for England. In the UK, the Forced Marriage Unit (FMU), based in the Foreign and Commonwealth Office is the national government department that provides assistance with forced marriage cases. They consistently report that they support around 1200-1500 cases per year across the UK and typically $80 \%$ of victims are women. In 2017, the FMU reported that $355(30 \%)$ cases involved young people under the age of 18 and a similar number $-353(30 \%)$ cases were aged between 18-25 years (Home Office \& FCO, 2018). This data is further broken down by UK regions and for Scotland, the FMU dealt with 18 cases representing $1.5 \%$ of total UK cases in 2017. Chantler et al (2017) found an average of 48 reported cases of forced marriage annually in Scotland between 2011 and 2014, based on responses from Scottish agencies. The true extent of forced marriage cases in Scotland is unknown, but Chantler et al figures are likely to be more accurate as the FMU is based in London, England and Scottish agencies and survivors may be more likely to contact locally based support.

Within the EU there have been three key legal interventions to combat Forced Marriage: i) civil remedies, ii) creating a specific criminal offence of forced marriage and iii) increasing the age of sponsorship and marriage for those marrying non EU nationals. Although the criminalisation of forced marriage is a requirement of the Istanbul Convention, it is a controversial decision and fiercely debated in Scotland. The UK has three separate legal systems: i) England and Wales; ii) Scotland and iii) Northern Ireland. The Forced Marriage etc. (Protection and Jurisdiction) (Scotland) Act 2011 (henceforth 'the 2011 Act'), came into force on 28 November 2011 and, provides civil protection in the form of Forced Marriage Protection Orders (FMPOs) for those at risk of forced marriage as well as those already in forced marriages. Although a civil order, breaching a FMPO is a criminal offence. A specific criminal offence of forcing someone to marry in Scotland was created under section 122 of the Anti-Social Behaviour, Crime and Policing Act 2014 (henceforth 'the 2014 Act'), and came 
into force on 30th September 2014. To date, there have been 16 FMPOs instituted in Scotland since 2011.

In this paper we argue that the concept of coercive control, as developed by Stark (2007) can also be applied to forced marriage. Stark's work has been transformative in understanding the subtle controlling behaviours that abusive men use to govern and restrict the women that they are in intimate relationships with. Our data illustrates very similar processes (albeit with different perpetrators) are used to coerce women in to forced marriage. Stark (2007) also argues that domestic abuse should be more accurately referred to as a liberty crime in which women are prevented from exercising autonomy whilst simultaneously being made to behave as their abusive partner chooses. We illustrate how the coercive control model is an excellent lens through which to understand the complex and multi-faceted dynamics of forced marriage. Concurrently, as Stark (2007) has argued in relation to domestic abuse, we also argue that forced marriage should more accurately be conceptualised as a pattern of behaviour because, as our data below indicates, most of the women were first introduced to their forced marriages in their preteen years and endured years of trauma leading up the actual event of the marriage. Additionally, for some of the women whilst the forced marriage itself was not actually contracted as women managed to evade the ceremony, the trauma of the process of being forced into a marriage was no less profound. For these reasons, we argue that it is essential to consider forced marriage as a pattern of behaviour rather than a discrete event and to consider the impact on women who both undergo the marriage contract and those who evade it.

We also draw on Liz Kelly's concept of the conducive context which she developed to argue that the contexts in which women were being trafficked for sexual slavery conspired to create the conditions which facilitated the women being trafficked (Kelly, 2007). Kelly (2007) considered the interplay between the immediate and transnational conditions that created the sympathetic environment for trafficking. Like Kelly (2007), we also apply this in a violence 
against women context but the manifestation is that of forced marriage. We use Kelly's (2007) concept to consider how both the immediate and wider context of girlhood, compulsory heterosexuality, family honour, cultural expectations and patriarchy conspire to constrain the agency that many young women face; particularly women in family contexts in which marriage carries cultural capital and is the only considered option for women.

\section{METHODS}

In 2015, the Scottish Government commissioned a team of researchers in partnership with three women's sector agencies, led by $\mathrm{KC}$, to undertake the first national study on forced marriage in Scotland. The study had three aims:

1. To investigate the level and profile of service use relating to forced marriage in Scotland

2. To analyse how services are responding to forced marriage in Scotland

3. To explore the impact of the interventions for forced marriage in Scotland

To address these aims we used a mixed methods case-study approach involving distinct work packages: a survey to understand the level and profile of service use; policy analysis and interviews with protection leads; interviews with professionals (e.g. police, social workers, and voluntary sector workers); as well as interviews with survivors of forced marriage to understand how services are responding to forced marriage and to analyse the impact of legal interventions. Detailed methods and results are available in the full report (Chantler et al, 2017).

MM conducted the survivor interviews and recruited across Scotland's specialist Black and Minority Ethnic (BME) third sector, Violence Against Women \& Girls (VAWG) organisations, and other organisations including LGBT youth Scotland. A dedicated Facebook page was also set up. Eight women who had survived forced marriage volunteered to participate in the study; recruited via these organisations or through 'snowballing'. Some of the women were still in dangerous situations and many were nervous about being identified by meeting 
with the researcher so all interviews were conducted over the telephone. The interviews followed a semi-structured interview topic guide and enquired about their understandings and experiences of forced marriage including the impact on their family relationships; help-seeking and coping strategies; legal interventions (civil and criminal); and about other forms of support. Interviews lasted around one hour with one significantly longer interview. Participants were offered a $£ 15$ voucher, as a thank you for their time. With permission, all the interviews were digitally recorded and transcribed verbatim. Data were analysed using an inductive thematic analysis (Patton, 1990) to draw out the main themes and facilitate comparison across the eight interviews. Ethical approval was granted by the Psychology and Social Work Ethics Committee at the University of Central Lancashire. The participants are referred to as Survivor 1 through to 8 to ensure anonymity and all identifying features have been removed.

The women ranged in age from 21 to 49 years although all their experiences of forced marriage occurred between the ages of 14 and 25 (the median age for the forced marriage was 18 years). This wide age range illustrated the commonalities of women's experiences of forced marriage over an almost thirty-year time span thus offering a temporal account of understanding forced marriage in Scotland. Whilst all eight women now live in Scotland, only three were originally from Scotland with three from other parts of the United Kingdom and the remaining two from South Asian countries (at the time of the interviews seven of the eight had British citizenship). The sample includes experiences of women born in the UK being taken to various South Asian and other countries; men being brought into the UK for the purpose of the marriage; women in the UK being married to South Asian British born men; and South Asian women from South Asia brought to the UK to marry British citizens, illustrating that there is no 'typical' geographical trajectory. Given the age, geographic and class background differences across the sample, the study has generated diverse accounts, which discuss behaviour, experience and context thus utilising the concept of 'thick description' (Geertz 
1973; Holloway, 1997). Whilst these eight accounts are unique to the women, the expectation of having a marriage arranged is normative for many young South Asian people but how typical these experiences are of the forced marriage process or post-marriage experience remains less known given the paucity of research in this area. Our study was informed by previous research including the work of Gangoli and colleagues (2006) in northeast England, which contrasted domestic abuse in love, arranged and forced marriage (FM) and the work of Hester and colleagues (2007) that interviewed 38 survivors of forced marriage, 33 women and five men.

Previous literature has indicated the difficulties of defining forced marriage (Hester et al, 2007; Chantler, 2012; NatCen, 2009). The definition of forced marriage used in this study was 'A forced marriage (FM) is where one or both spouses do not (or cannot) fully and freely consent to the marriage, and duress is involved. In this study, a 'case' of FM can either be the threat of, or the actual occurrence of, a forced marriage. This definition is in line with other studies (Hester et al, 2007; NatCen, 2009). As illustrated by the testimonies of the women below, it is important to consider forced marriage as a process rather than a singular event because for some women, the start of this process began in early childhood and for others whilst the marriage ceremony was evaded this did not diminish the trauma or impact of the experience. Participants recounted their experiences of being forced to marry describing loss of liberty and betrayal but importantly also their resistance. Significantly, all of them rejected their marriage proposals.

\section{FINDINGS AND DISCUSSION}

Our data analysis identified five key themes form the survivor interview corpus: i) survivor understandings of forced marriage; ii) the 'grooming' process; iii) intersections of familial and service betrayal; iv) women's perspectives on legal remedies ; and v) women's resistance. Each of these themes is discussed in turn.

\section{Theme 1: Survivors' Understandings of Forced Marriage}


Whilst policy documents make a clear delineation between arranged and forced marriage (Scottish Government, 2011; 2014), centred on the presence or absence of consent, the lived experiences of women in our study demonstrate that the demarcation between these categories is more fluid. For example, Survivor 4 was engaged at the age of eight, and taken from the UK to a South Asian country at age 15 to be married to a stranger. Despite her lack of consent, forced removal to another country and being a child at both the time of the engagement and the marriage ceremony, Survivor 4 describes this as an arranged rather than a forced marriage. Anitha and Gill (2009, p. 165) argue 'that consent and coercion in relation to marriage can be better understood as two ends of a continuum, between which lie degrees of socio-cultural expectation, control, persuasion, pressure, threat and force'. This analysis aligns more closely with survivor narratives in our study as illustrated by the following:

"At that time, I thought that's what was expected of me and that was the norm. It's just that I didn't fit into that norm. But now I see it as, with more information, that it was a forced marriage. I was forced emotionally and blackmailed constantly and pressurised constantly and threatened sometimes saying 'if we see you, we're going to break your legs'.'(Survivor 1)

Further, the participant's understanding that emotional force was used resonates with Stark's (2007) concept of coercive control as the victim makes it very clear that she was expected to conform to her parents' code of conduct regarding the impending marriage. Leaving the parental home as a way of resisting the forced marriage would also result in physical chastisement so Survivor 1 is caught in a double bind. Stark's (2007) concept of coercive control and the notion of a liberty crime are also salient as full and free consent to marriage is intrinsic to the declaration of human rights and is also articulated in general recommendation 21 , article 16 in the UN Convention of the elimination of discrimination against women (CEDAW, 1994). 
A further complication is that women's constructions of forced marriage tend to be associated with physical violence rather than the emotional abuse or cultural pressure exerted upon them as illustrated in our data below. The occlusion of emotional abuse also relates to Stark's (2007) work that highlights the salience of the emotional domain in abuse contexts, yet evidence for controlling psychological behaviour can be hard to evidence. The privileging of physical violence has also been the mainstay of the criminal justice system in Scotland (as elsewhere) and it is only recently that coercive and controlling behaviour has been seen as a criminal offence in English and Welsh legislation under the Serious Crime Act 2015. Coercive and controlling behaviour has recently been incorporated into the Domestic Abuse (Scotland) Act 2018. In our data, the privileging of physical violence is important as it impedes women from accessing support where other domains of violence against women are used. Some of the women discussed how they did not define what had happened to them as a forced marriage because they had perceived a forced marriage victim as a young South Asian girl being kidnapped to a South Asian country and physically forced into a marriage contract, and their own experience often did not reflect this. Therefore, because their own experience did not replicate this particular construction of forced marriage they were then unable to identify, or label what was happening to them, as forced marriage, as illustrated by Survivor 3:

“the reason I didn't think of contacting the police, because, honestly I didn't think it was a matter the police would have dealt with because my parents were not shipping me off to [South Asian country] to get married. They weren't holding a gun to my head. I know that sounds a bit extreme but or the wedding wasn't taking place the next day. I didn't think the police, that it would matter to the police. It wasn't like I had to say yes because I knew, OK, my mum's now thinking of getting me married off, I started saving up, now I know the date is approaching, I started looking for a flat, I 
didn't think of it being a matter the police would get with because I wasn't, it was just, there was no evidence, no proof that this was actually happening." (Survivor 3)

Additionally, because she did not believe that her experience met the threshold of a forced marriage, she was also concerned that she did not have 'evidence' to corroborate what was happening to her. Both of these factors combined with her personal and financial resources, although limited, equipped her with some options to escape, but further compounded her view that she did not meet the definition of a forced marriage victim. Arguably, this further illustrates the limitations of considering a forced marriage as only one in which the marriage is contracted because, as illustrated above, Survivor 3 had not yet been married which may also have contributed to her not identifying her experience as forced marriage. However, even experiences that do reproduce the 'typical' representation of forced marriage, as discussed below, are still not always recognised as such by the women experiencing it. This disjuncture between how young people, policy makers and support organisations construct forced marriage is a significant barrier in the identification of forced marriage and is antithetical to prevention and early intervention work.

\section{Theme 2: The 'Grooming' Process}

Conceptualising forced marriage as a process rather than an event, allows the dynamics of this form of abuse to be more visible and attests to the often long-term process of socialisation starting in childhood. Mothers are key to such socialisation and as argued by Yuval Davis (1997), mothers are not only biological reproducers but 'cultural' reproducers for the nation, thus they have a key role in the transmission of appropriate cultural values, created largely through a patriarchal structure. All participants in our study discussed the instrumental role their mothers played in introducing the idea of marriage to them as young children or adolescents. Survivor 4 engaged at eight and married at 15; Survivor 6 engaged at 14 to a man 18 years her senior (whilst this marriage was not contracted she was then married at age 16 to 
a different man). Survivor 3 was introduced to the idea of marriage at 13, which was planned for when she was 20. She reported:

"Yeah, I've always had concerns because my mum especially, I think my dad, my dad's clearly a liar and he can be quite a manipulative person. But my mum as well, like I know that she will do more what the culture and society expects from her, not what is actually best for her children, and herself as well, I would say." (Survivor 3)

We argue that it is important to recognise the problematic positioning of women as mothers as responsible for the perpetration of forced marriage when, arguably they are also working to the same cultural script within the confines of patriarchal control that coerces them into forcing their own children to marry (Kandiyoti, 1988; Aplin, 2017). Importantly, neither are we suggesting that these mothers lack complete autonomy or agency and are simply blindly reproducing the demands of patriarchy because as Young Larance and Miller argue "women can and do use violence" (2017, p. 1536), either in an instrumental way or more often in selfdefence particularly in relation to protecting their children (Swann et al, 2005; Hester, 2012).

Survivor 2, discussed how, as a school student, her parents would show her photographs of men: "they weren't asking me whether I liked any of them or anything, they were just kind of planting the seed for me by these photos". As an adult, Survivor 2 can now recognise this as a process of normalisation of early marriage and that her parents were preparing, or grooming, her for this from a young age. Arguably, there are similarities with the grooming of child victims for other abusive behaviours and we would argue that being 'groomed for marriage' is a more accurate description of this marriage process. However, 'grooming' also needs to be understood within a context of normalised heteronormativity in society in general and whilst marriage may not be as salient in Western cultures compared to South Asian cultures, the socialisation into heteronormativity is (Chantler, 2014). Significantly, earlier marriage ages in many minoritised communities is encouraged as women's expression of sexuality is considered 
undesirable because of reputational issues (Gangoli and Chantler, 2009), thus mothers play a key role in the socialisation of their daughters. Bates (2017) study examined UK databases of police forces and voluntary sector agencies supporting victims of honour based abuse and found that mothers were most frequently at the forefront of their daughters' forced marriages. Whilst this article does not analyse in detail the forms of 'patriarchal bargain' (Kandiyoti, 1988) involved in mothers' roles in forced marriage, we are aware of the dangers of blaming mothers where gender relations within family contexts are not simultaneously scrutinised. This can be particularly problematic as many of the survivors in our study were forced to marry their cousins. For example, Survivor 4, British born, was taken to a South Asian country and forced to marry her cousin to whom she was engaged to since age 15 . She stated that her mother was too scared to reject the marriage proposal conveyed by her brother. It is apparent that proposals from close family members (first cousins) is both commonplace and a compounding factor in restricting the possibility of rejecting the proposal, as illustrated below by Survivor 6: "It's quite scary, I was very young so, the first time when I'd been forced to get married I was 14. So the first impact it went on my study and it was so scary. I was just like every normal child, crying a lot and I did not want to get married and especially the guy I got engaged, he was 18 years older than me. He was 18 years older than me, he was my first cousin. My mum couldn't say no to her [sibling], so that's why I, family pride, why she has to force me. So they had to beat me up to not say no to him because I want to say no to him straight away." (Survivor 6)

Cousin marriage can position mothers in difficult situations whereby to reject the proposal would be to reject their natal family. Given the smallness and intensity of some communities in which forced marriage is practised in Scotland, this can also mean rejection or ostracisation from the wider community and ultimately no marriage for her daughter/s. Here it is also useful to draw on Kelly's (2007) concept of conducive contexts. Whilst Stark (2007) focuses on 
interpersonal processes of control, Kelly's (2007) concept of the conducive context is also useful as it alerts us to locating forced marriage within the ambit of a conducive cultural context that contributes to naturalising forced marriage. In addition, as we illustrate below the concept of conducive contexts can also be extended to encompass a number of structural factors. Nevertheless, the role of mothers as simultaneously part of, as well as pressurised by, the conducive context is central to understanding the operations of power in family contexts of forced marriage. In this survivor's experience, there is also a detectable sign of ambivalence displayed by her mother in the process of coercion:

"my mum was also crying and sometimes being comforting, sometimes being extremely, one second she's very comforting and the next she was like extremely angry and then there was yelling and screaming. So this went on for like two days and two nights, so I was in one room, I keep saying 'no', she keeps asking 'why, why, why, why not?' And then you go from one room to the next room and she will follow you there, then downstairs, upstairs. I think I locked myself in the bathroom for a while and she kept banging the door and it was things like that and I think eventually at the end of the day I caved in and eventually after two days and two nights I just told her 'OK, fine, just do whatever it is that you want to do' and that was that.' (Survivor 5) Survivor 7 (UK born) was taken at the age of 15, to a South Asian country to marry someone she had never met and was detained there for almost one year by her mother, and other family members, and was only permitted to return to the UK when pregnant and beyond the legal limit for a termination in the UK. Survivor 7 recognises her experience as a forced marriage because she had repeatedly expressed her objections to her mother:

“I think it was forced because my mum knew how much I didn't want to get married. Same as my brothers and sisters, they didn't want to get married, but mum's orders 
was mum 's orders, we couldn't go against mum. Mum was kind of, she was kind of strict, a strict Muslim." (Survivor 7)

However, it should be noted that forced marriage is not permitted in Islam (Gill \& Hamid, 2016). This participant also discussed the forced marriage of her siblings who endured severe beatings from their mother when they objected to their proposed marriages and she spoke in particular about her sister who is a lesbian and was treated the most savagely by their mother. Theme 3: Intersecting Familial and Service Betrayals

All the women in this sample are victims of abuse, violence and controlling behaviours. All managed to escape, both pre and post marriage, but some were trapped for many decades before their escape. The experiences in this sample covers emotional and psychological abuse, physical violence, sexual violence, imprisonment, torture, forced starvation, financial control, isolation, being forced to commit criminal acts and experiencing other criminal, degrading and humiliating treatment; in addition to the sexual, physical and emotional abuse and neglect of their children, and forced estrangement from children. The abuse was committed both by natal family members, mostly mothers (pre-marriage), and by husbands / husbands-to-be with familial support. Not only were the women betrayed by their families but other structural systems, knowingly or unwittingly, colluded in this abuse. This section explores the various betrayals that the women were subject to throughout their forced marriage experience.

Survivor 1 discusses the way she was deceived into a marriage by her mother, aunt and wider family members who 'encouraged' her to go on a family visit to South Asia where, unbeknown to her, her wedding had been arranged.

"from the age of 19 they would say 'Okay, he's 40 but it's alright, you need to get married' but I delayed it. Then I think one day they said 'look, why don't you go and see your aunty in [South Asian country] just for a holiday, you've been feeling down' and I said 'alright'. It sounded good for going to [South Asian country]. So when I 
went there they said oh there was people coming to see me, I was told to wear certain dressing. Sorry [participant crying]. So, I said 'look, I don't want to marry anybody here, I don't want to be in this [South Asian] country.' But they said 'no, you have to get married' I said 'OK, I'll just get engaged first'.' (Survivor 1)

Not only was she betrayed by her immediate family members but was removed from the education system (in Scotland) at the age of 12 with no investigation by the school or other professional into to her disappearance. In her view, there was a gendered dimension to her education being restricted in a way that did not happen to the boys:

"I was at college, but they took me out of college. I would try to go back to college, they would take me out, didn't want me mixing. I was actually taken out of school when I was 12. ... because they didn't want me to have an education because that makes the women more empowered." (Survivor 1)

Disrupting education was a common theme for the participants and Survivor 4 also recounted how she was removed from school at the age of 15 :

“Yeah, it upsets me 'cause I can't read well. I can read, but I can't, I can't spell, I can't write and it really hurts because I shouldn't have been out of school at that age. And even though we did go to school, we used to go to school for a day and then mum used to not let us go for weeks because at that time you could get away with it. And they just didn't allow it, they said 'oh girls can't be allowed to go to school, Muslim girls shouldn't be allowed to go to school because they get communicating with boys. So they shouldn't be allowed.' So we wasn't allowed to go to school as normal girls." (Survivor 4)

Not only is the family jeopardising the life chances of Survivor 4 but the account begs the question of how school attendance was monitored and absences followed up. A coherent and robust school policy would have ensured that pupils that miss school on a regular basis are 
followed up and that appropriate action taken with fewer missed opportunities for intervention. However, given that this survivor was discussing experiences from twenty years ago, it is less likely that this level of withdrawal would be possible in Scotland today due to improvements in practice such as the implementation of Getting it Right for Every Child (GIRFEC). GIRFEC is the national policy framework in Scotland to support the wellbeing of all children and young people and improve outcomes (Scottish Government, 2017). This should, in theory, ensure that lack of attendance should not go unnoticed or without investigation. Furthermore, even with the right policies in place, it is their implementation that will be central to interrupting forced marriage.

Survivor 4 was taken to a South Asian country to marry and then held captive there. She was only permitted to return to the UK when seriously mentally unwell due to the trauma of being kidnapped, forced to marry, witnessing the murder of her husband and being pregnant with her second child. Upon returning to the UK, she was then forced, for a second time, to marry the brother of her deceased first husband, who was violent and abusive. She fled to Scotland to escape his brutality but never had any support from her natal family and still lives under constant fear and threat of her husband and his family finding her.

Both Survivor 1 and 4 are aware that their treatment was correlated to their gender and whilst both participants are in their 40s reflecting on experiences that first happened over twenty years ago, both Survivor 6 and 7 in their thirties also had similar experiences despite the ten year gap. As discussed above, Survivor 7 was removed from school at 15 and taken to South Asia to marry. She reported that her mother had a history of controlling, manipulative and violent behaviour towards her and her siblings and she remains estranged from her natal family. However, upon giving birth her mother forcibly removed the child and refuses to relinquish the child, now aged 10, unless Survivor 7 returns to South Asia and reunites with 
her husband. Survivor 7 did call the police in to try to get them to help her get her child back from her mother and states that:

“she's got no right to stop me to see my child, but obviously she's sticking to her guns and saying that, you know, 'you've got to get back to your husband'. But that didn't work out, the police couldn't even help me." (Survivor 7)

Now in her early 30s, Survivor 7 also discussed her feelings of rejection and abandonment by the systems that she believed are meant to care for children:

"No, I mean we didn't come back to school, I think by the time we come back [from South Asian after the wedding] school was all over. I mean I think that's why I was more hurt, the fact that no-one come looking for me. You know a doctor, no-one and I was really, really hurt, the fact then, more and more I thought that you know what? I was an unwanted person in this world. I had stupid things in my head thinking that, 'look, how come no-one even asked for me? How come no-one found me?'”

(Survivor 7)

Her sense of betrayal by the protection systems is clear in the following:

"At the time when I was going through all this I mean somebody could have put a stop to it. Somebody could have put a stop to this all. Somebody could have saved me from getting married. And then when I was gone for a year, I mean somebody could have got me back and said 'you know what? No'. But [it] just never happened. I think that's what kills me the most because you know, no-one brought me back. I was that girl in [South Asian country], getting beat up, crying, asking for help and no-one heard me." (Survivor 7)

Survivor 2 also had her education interrupted when her parents removed her from University in order to get married. Despite disclosing to the university counsellor that she was going to be taken out of the country and forced into a marriage there was no support or help offered to her 
by the counsellor or the University. This account illustrates that even when women reach out for help, they cannot be guaranteed adequate protection. Once married, she was made to join her husband in the country in which he was living and became physically, socially and emotionally isolated from all family and friends. Her husband was physically violent, abusive and controlling throughout their time together but when she approached her parents for help was told: "if I was a good wife then he wouldn't hit me".

Survivor 8 had a similar story of betrayal from her natal family and her in-laws who covered-up the husband's abuse and violence. When seeking support from her mother-in-law about the sexual violence she was told to: "give him what he wants, then he'll be happy". She then asked her own mother to intervene but was similarly told:

“"what do you expect? You're married. Men have their needs.' And she said to me 'if you give him a lot of what he wants, he'll get sick of it'. So basically she was saying have sex with him more than what you already are, and do more, more things of a sexual nature with him, to the point where he gets bored of it and won't come near you." (Survivor 8)

The abuse the women experienced was not just from the husbands but, as in the case of Survivor 6, from the husband's immediate and wider family. At 16 she was married to a UK man and brought from South Asia to the UK live with him. She was completely isolated from her natal family and subject to years of sadistic cruelty and violence. Her husband's parents, siblings and siblings-in-law colluded in the violence and abuse and manipulated social services, health professionals and the police so that they all colluded in the ongoing abuse and violence. Survivor 6 finally escaped with her children and resettled elsewhere in the UK but was then forced by her natal family to reconcile with her husband (despite them knowing of the cruel and inhumane treatment, abuse and neglect of her and the children). Upon reconciliation the violence and abuse started immediately and again she managed to escape with her children. 
Survivor 6 also discussed how her husband's family duped the health visitor into believing that Survivor 6 was the daughter of her mother-in-law and the maternal grandmother of the child in order to cover up the abuse and mistreatment of Survivor 6 and her child. On occasion Survivor 6 was present at these meetings but was not permitted, and was too scared, too speak but did explain that she thought that the health visitor did have concerns: "she [health visitor] was suspicious 'well, you're not too close to your mum, your mum doesn't talk to you very much"'. Survivor 6's story illustrates the multifarious betrayals from her natal family, in-laws, and the manipulation of the systems whereby professionals involved with the family failed to see the ongoing abuse.

A further example of being let down by services very recently is illustrated in the case of one of our participants who had used the 2011 Act to obtain a forced marriage protection order (FMPO). She reported that, while she was pursuing a FMPO, she experienced a number of breaches of her confidentiality from statutory sector professionals involved in her case, with her telephone number and subsequent address, and details of her key worker, being given to her parents despite explicit instruction that there was to be no contact with parents or other family members. However, Survivor 5, also discussed the positive support she had received from a range of statutory services. Other survivors particularly valued support from voluntary sector organisations. Referring back to Kelly's (2007) concept of conducive contexts, we can see how and whether professionals intervene has a key bearing on the context and outcome of forced marriage. For example, aspects of Survivor 5 case where agencies had been supportive and sensitive we argue that this serves to disrupt the conducive context of forced marriage and, conversely, where responses have been less satisfactory as in Survivor 6's case, they bolster conducive contexts.

\section{Themes 4: Women's Perspectives on Legal Remedies}


A key part of the interviews with survivors was to explore the impact, if any, of the implementation of the recent legislation (2011 and 2014 Acts) on those with experiences of forced marriage. However, we struggled to recruit women with experiences post-2011 and so extended the remit to include women with experience of forced marriage pre-2011 and discussed their views of the legislation. One of our participants had utilised the 2011 legislation and obtained a forced marriage Protection Order [FMPO] and this is discussed below (in the interests of anonymity we will not indicate which of the eight women it is).

The view of the majority of the women was that whilst they welcomed both the civil and criminal legislation it is not something that they would use: "Because you love them [parents/family members]. There's no way you're gonna put a criminal record against them or want to do something that will, you know, they get letters through the courts or anything" (Survivor 1). This participant also argued that criminalisation is "making girls go underground" because "nobody wants to drag their parents through the courts." This is reiterated by Survivor 2 who emphatically rejects the criminalisation of forced marriage: "I mean there's no way, gosh, no, there's no way I would have gone down that route. There's no way at all, even now, I would never have gone down that route." Participant 7 explains that even calling the police on her mother led to a lot of "hassle" from her brothers who threatened her for doing so illustrating how the wider family can collude against the victim. Similarly, Survivor 8 discusses how her family operated as a unit against her to pursue the forced marriage. Part of the grooming process to prepare her for marriage was to isolate her from any external social support which has implication for recourse to legislative support:

"No because my family had isolated me, whether it was intentional or not, to only rely on them and to not have much contact with the outside world. If I was then to move forward with any sort of legal proceedings against them, under the capacity of the Forced Marriage Protection Order, I would have been disowned by them and I would 
have been at a loss and I would have been socially isolated from the community. No way, I couldn't possibly consider that." (Survivor 8)

However, even the civil legislation, would be redundant for some such as Survivor 1 because she was entirely unaware of what was happening until she arrived in South Asia. Furthermore, she says if she was aware of what was happening she probably would not have used the legislation because she internalised the blame for what was happening rather than seeing her parents has culpable: “I don't think I would have used it because for me, it was like I was doing something wrong. But now I would think, if I was that girl now with the information I had, I probably would use it now." The participant that had obtained the FMPO stated that she feels "a lot safer" with the order in place, but does not think it is a strong enough deterrent and that criminalisation is essential as a last resort. However, she also commented on the difficulties of obtaining the order:

"I just wish that the whole case thing, it's like...the case is like, you sort of have to prove... whether you were being forced or not and they have to prove that they were being loving and...rather than being forced, it's a bit...it's a bit like going through a divorce case, it's what I'm actually going through, something like that ...that was my experience, so far anyway, of the Forced Marriage Protection Order."

The onus of responsibility is thus on the survivor to prove that she is being forced to marry and as it is much harder to prove emotional pressure, the process of utilising legal remedies is reported as:

"So...messy and stressed and...psychologically it's quite stressful, I think it's very important to have a good solicitor...pick a good solicitor and often finding a good solicitor is like half the battle because no-one really knows... a lot of the agencies don't really know where to turn to..." 
Conversely, Survivor 8 argues that legislative response will never be effective and instead prevention work is required to educate communities:

"What needs to be done is education within the community, as in what is an arranged marriage? What is forced marriage? What's the difference between the two and talk about things that are taboo subjects within black minority ethnic communities.

Honour killings, honour based violence, shame in the community, it all needs to be brought forward. And that's why there's a lack of people coming forward for the project because we're scared. It's instilled, this fear is instilled into us." (Survivor 8) The combined experiences of these eight women spanning 25 years illustrate the maltreatment by family members, husbands, and inadequate practice by some welfare and protection systems. Whilst all women escaped their forced marriage this has come at a high personal cost and for many their situations remain precarious. However, what stands out is the resilience and resistance of these women. For some of the women, the resistance involved a temporary break in communication with natal families whilst for others this has been permanent. The next section will consider some of these strategies of resistance.

\section{Theme 5: Women's Resistance}

All the women had strategies for resistance, which they implemented at various stages of their forced marriage journeys. For example, Survivor 1 managed to postpone her marriage from the age of 19 until 25 by making herself ill through disordered eating because "nobody wants to marry an ill woman". At 25 she was taken from the UK to South Asia for the wedding and as a strategy to evade the wedding being contracted she agreed to the engagement but requested a six months postponement to return to the UK and prepare for the marriage. However, upon her return to the UK she went into hiding and successfully avoided the marriage being contracted. Survivor 3 has a similar experience of successfully postponing her wedding from age 16 to 20 . This facilitated her finishing her schooling and starting University. However, in 
order to escape the wedding that her mother was preparing she also ran away from home and has, to date, successfully avoided the wedding. Whilst both these women avoided the marriage contract, Survivor 2 ran away after the marriage was contracted but refused to stay with her husband despite family pressure to return to him. She also managed to return to higher education and continue the degree course she was studying before being taken abroad for marriage.

In the early stages of her forced marriage process, Survivor 5 also used food restriction as a way to regain some control over her life and then attempted suicide (numerous unsuccessful attempts) when she believed that she had ran out of other options. Of all the women interviewed, Survivor 6 suffered the most encompassing abuse and violence including imprisonment and abuse of her children. Despite insecure immigration status, no recourse to public funds, limited English language, no passport or understanding of the UK legal system, and pressure from both her natal and her husband's family she has managed to build herself a safe new life with her children. Through support from statutory and specialist third sector services, she has gained a new confidence, has filed for divorce and is learning new life skills.

Survivor 8 also used similar tactics to some of the other participants where she used higher education to postpone her marriage whereby her mum agreed that she "would marry him the week after I graduate". Whilst these concessions may seem minimal and to simply prolong the inevitable forced marriage they gave the women some control back into their lives. Once she was married, Survivor 8 implemented other tactics of resistance such as avoiding her husband's parents when they came to visit:

"I used to lock myself in the bathroom so I didn't have to speak to them but that didn't go down well as you can imagine. I used to have to pretend I was constipated 'cause I didn't want to talk to them and I didn't want to be told what to do. So I just used to sit in there and lock the door!" (Survivor 8) 
As a young woman Survivor 4 was traumatised when she was taken abroad at 15 to be married and then at age 18 witnessed her husband's murder whilst pregnant with her second child. Even though custom dictates a four months mourning period she threatened suicide if not permitted back to the UK. When Survivor 4 was then forcibly married to her brother-in-law who was extremely violent and abusive, she again tried to end her life. Despite numerous attempts to commit suicide she survived and managed to escape to Scotland with her children:

"I've tried to commit suicide so many times because I sort of give up on life. I didn't know there was help out here. I've just come to Scotland and now I know there's help out here and that's how I encourage my [child] now and say, 'look, there's help out here, if you need help, there is help'." (Survivor 4)

There were also very empowering methods of resistance used, most notably for those survivors who had children discussed how their experience has made them parent their own children differently to how they were raised. Survivor 1 states: "I want them [children] to have more freedom than I did. Choices, options. Not so authoritative to my children." Survivor 2 cannot comprehend the behaviour of her parents: "after having my own kids, I just think how could they do that?" And Survivor 4 who states:

"I've got [children] and I'm never going to let them go through what I've been through. I'm trying to give them the confidence. I've brought them over here and I'm going to give them the confidence of marrying who they want and who they love and let them educate themselves in doing what they want. I'm never going to get in the way, never. And I'm going to try and let them have an education what I didn't have." (Survivor 4)

Survivor 7 echoes similar sentiments but also discusses how her experience has made her reject her religion and gendered constraints on her children: "I've not put no Muslim law on them 
[children], I don't force them to be a Muslim, they want to be who they want to be. I want to give them the life that I never had" (Survivor 7).

Despite the restrictions on her life, Survivor 4's resistance is evidenced through living a happy life with her children and wanting other women to know that survival is possible. Whilst some women's strategies of resistance may have been harmful to themselves, these need to be understood as a response to the duress they were experiencing and the only method in which they were able to exert some measure of control.

\section{CONCLUSION}

Based on eight in-depth interviews with survivors of forced marriage, we utilised two key theoretical frameworks for analysing our interview corpus. Firstly, Evan Stark's (2007) work on coercive control has been extended in this paper to move beyond intimate partner situations to those of forced marriage. The privileging of physical violence both in intimate partner relationships and in forced marriage as illustrated above, maps on well to Stark's ideas. Stark's (2007) notion of a liberty crime as a method of curtailing and controlling another's behaviour and preventing women from doing what they want is evident in the accounts presented here. Denying women's autonomy and choice in relation to marriage and forcing them to marry is a clear example of a liberty crime as well as a breach of internationally accepted human rights. Importantly, our participants also described how their education was disrupted and how they were prevented from attending school and college. We argue that this also constitutes a liberty crime as women who were denied their education continue to live with its impact. To understand the context of forced marriage and moving beyond the coupling of Stark's (2007) work, Liz Kelly's (2007) framework of conducive contexts has been particularly useful in the analysis of our data. This analytic frame allows for a nuanced and multi-layered analysis by illuminating the under-appreciated dynamics relating to gender-based violence in particular contexts. In our study, we analysed the accounts of eight survivors of forced marriage who 
despite having different geographical trajectories all inhabited South Asian cultures. In our analysis, factors which constitute conducive contexts for forced marriage include heteronormativity; strong normative expectations and traditions of marriage; girls and women's subordinate status; prescribed gender roles; social (protection) systems which sometimes fail to protect victims of forced marriage; and insecure immigration status which compounds issues for South Asian women on spousal or other temporary visas. Some of these factors have also been reported in previous work on forced marriage and domestic abuse in England (Anitha, 2011; Burman and Chantler, 2005; Hester et al, 2007). Whilst conducive contexts normally apply to men's facility to perpetrate gender based violence, our analysis demonstrates the role of mothers in upholding family, kinship and cultural values of marriage and participating in forced marriage within gendered contexts of family relations. This is a new finding which has also recently been found by Bates (2017) in her work on forced marriage. The role of mothers-in-law in domestic abuse in South Asian contexts has been illustrated by Chaudhuri, Morash and Yingling (2014) and argued by Gangoli and Rew (2011). The role of mothers and mothers-in-law in these contexts has to be understood as part of a patriarchal family system in which male privilege is frequently sustained by 'patriarchal bargains' (Kandiyoti, 1988). Kandiyoti (ibid) argues that women in patriarchal contexts negotiate these by making bargains to secure, for example, their financial security and social status and recognises the uneasy position between gender norms within a particular a context, agency and pay-off (see also Gerami \& Lehnerer, 2001; Shankar \& Northcott, 2009). Mothers' roles in forced marriage can be conceptualised as reproducing patriarchal relations whilst bargaining to improve their own gendered position and cultural capital within families and communities. Whilst not condoning the role of mothers in forced marriage, we are equally aware of the necessity to situate this within the wider framework of patriarchal bargaining and to recognise the constraints on mothers' own agency. A gender-based analysis, must acknowledge the 
complicity of women in perpetuating patriarchal systems of power and whilst the scholars above have written on this, this area needs further empirical and theoretical development.

It is evident that forced marriage is a complex issue covering a long period of time with the marriage itself just one element in this process. For some women the process of being forced to marry spanned many years and strategies of resistance such as delay and avoidance were commonplace. For those women who did marry, their exit from those marriages was difficult, including marriages followed by domestic abuse. The same tactics used by families to force their daughters to marry were also used to keep daughters within the marriage. The longevity of the impact on the participants illustrates the importance of considering forced marriage as a process, rather than a singular event. Legislation or policy that constructs forced marriage in the narrow way discussed above, only applies to some of these women and girls and even then many would not see themselves as 'victims of forced marriage'. Further, legislation alone is not sufficient to tackle forced marriage. Preventative community level education is key to achieving the cultural shift required to combat forced marriage (Chantler et al, 2017). As other feminists have argued, the marriage process is less about culture or religion and more about patriarchal privilege and this must be retained in any analyses of forced marriage.

Far from women being passive, the women in our research demonstrated great courage and determination and most approached either formal or informal sources of support. However fundamental to the perpetration and perpetuation of forced marriage is the understanding that women are not regarded as autonomous beings but are constructed as chattel, first under the ownership of the natal family and then of the marriage family:

“you become almost like a commodity that's sold and it's very much an objectification of a woman that certainly within the [South Asian] community that once you are married, you are then owned by your in-laws, therefore, you are no longer a responsibility of your own family, your blood family." (Survivor 8) 
Despite their subordinate status, the women highlight the contact with services that illustrate the many and varied missed opportunities for intervention as discussed above. Further, the process of using the new forced marriage legislation is not straight forward and this may contribute to the relatively low take-up of this provision. Finally, as the ambiguity over the efficacy of the legislation by those it was designed to help indicates, we must keep forced marriage survivors at the heart of this work because they are experts by experience from whom we can and should learn. Additionally, speaking to these women and listening to their stories is a responsibility that we all share.

"It feels nice talking to someone, getting things off your chest and telling someone and you listened to me. Thank you so much for listening to me. I've never had that kind of person to listen to me, so I feel really proud that I've talked to you". (Survivor 7) 


\section{References}

Aujla, W., \& Gill, A. K. (2014). Conceptualizing 'honour' killings in Canada: An extreme form

of domestic violence? International Journal of Criminal Justice Sciences, 9, 153-166.

Retrieved from: http://www.sascv.org/ijcjs/pdfs/aujlagillijcjs2014vo19issue1.pdf

Anitha, S., \& Gill, A. (2009). Coercion, consent and the forced marriage debate in the UK. Feminist Legal Studies, 17, 165-184. https://doi.org/10.1007/s10691-009-9119-4

Anitha, S. (2011). Legislating gender inequalities: The nature and patterns of domestic violence experienced by South Asian women with insecure immigration status in the UK. Violence Against Women, 17, 1260-1285. https://doi.org/10.1177/1077801211424571

Aplin, R. (2017). 'Exploring the role of mothers in 'honour' based abuse perpetration and the impact on the policing response' Women's Studies International Forum, 60, 1-10 https://doi.org/10.1016/j.wsif.2016.10.007

Bates, L. (2017). Honour based violence in England and Wales. University of Bristol PhD thesis: Bristol.

Burman, E and Chantler, K (2005) Domestic violence and minoritisation: Legal and policy barriers facing minoritized women leaving violent relationships. International Journal of Law and Psychiatry, 28 (1). pp. 59-74. https://doi.org/10.1016/j.ijlp.2004.12.004

CEDAW (1994). UN Committee on the Elimination of Discrimination Against Women (CEDAW), CEDAW General Recommendation No. 21: Equality in Marriage and Family Relations, $\quad 1994 . \quad 13.11 .17 \quad$ Retrieved from http://www.refworld.org/docid/48abd52c0.html

Chantler, K. (2012) Recognition of and Intervention in Forced Marriage as a Form of Violence and Abuse, Trauma, Violence, \& Abuse, 13 (3). pp. 176-183. https://doi.org/10.1177\%2F1524838012448121 
Chantler, K (2014) 'What's Love got to do with Marriage?' Families, Relationships and Societies, Volume 3, Number 1, March 2014, pp. 19-33(15) https://doi.org/10.1332/204674313X13794148714614

Chantler, K., Baker, V., MacKenzie, M., McCarry, M., Mirza, N. (2017) Understanding Forced Marriage in Scotland, Edinburgh: Scottish Government, available at: http://www.gov.scot/Resource/0051/00513514.pdf

Chantler, K. and Gangoli, G. (2011) Domestic Violence in Minority Communities: Cultural Norm or Cultural Anomaly? In R. Thiara, M. Schroettle \& S. Condon (eds): Violence against Women and Ethnicity: Commonalities and Differences across Europe. Opladen: Barbara Budrich pp. 353-366

Chaudhuri, S., Morash, M., \& Yingling, J. (2014). Marriage Migration, Patriarchal Bargains, and Wife Abuse: A Study of South Asian Women, Violence Against Women, 20 (2), 141-161. https://doi.org/10.1177/1077801214521326

Gangoli, G., Razak, A., \& McCarry, M. (2006). Forced marriage and domestic violence among South Asian communities in North East England. Bristol, UK: School for Policy Studies, University of Bristol and Northern Rock Foundation.

Gangoli, G. and Chantler, K. (2009) Protecting Victims of Forced Marriage: Is Age a Protective Factor? Feminist Legal Studies, 17 (3). pp. 267-288.

Gangoli, G., \& Rew, M. (2011). Mothers-in-law against daughters-in-law: Domestic violence and legal discourses around mother-in-law violence against daughters-in-law in India. Women's Studies International Forum, 34, 420-429. https://doi.org/10.1016/j.wsif.2011.06.006

Geertz, C. (1973). The Interpretation of Cultures. New York: Basic Books, Inc.

Gerami, S., \& Lehnerer, M. (2001). Women's agency and household diplomacy: Negotiating 
fundamentalism. Gender $\quad \& \quad$ Society, $\quad 15, \quad 556-573$. https://doi.org/10.1177/089124301015004004

Gill, A. and Hamed, T. (2016). Muslim Women and Forced Marriages in the UK, Journal of Muslim Minority Affairs, $36 \quad$ (4) $\quad 36.540-560$. https://doi.org/10.1080/13602004.2016.1260324

Haraway, D. (2004) Situated Knowledges: The Science Question in Feminism and the Privilege of Partial Perspective in S. Harding (ed.) The Feminist Standpoint Theory Reader: Intellectual and Political Controversies pp. 81-101, London and New York: Routledge

Harding, S. (1991). Whose Science? Whose Knowledge? Thinking from Women's Lives. Milton Keynes: Open University Press.

Hester, M., Chantler, K., Gangoli, G., Devgon, J., Sharma, S. and Singleton, A. (2007). Forced marriage: the risk factors and the effect of raising the minimum age for a sponsor, and of leave to enter the UK as a spouse or fiancé(e), Bristol and Manchester: School for Policy Studies, University of Bristol and School of Nursing, Midwifery and Social Work, University of Manchester. Retrieved from http://www.bristol.ac.uk/sps/research/projects/completed/2007/rk6612/rk6612finalrep ort.pdf

Hester, M. (2012). 'Portrayal of Women as Intimate Partner Domestic Violence Perpetrators' Violence Against Women, 18(9): 1067-82. https://doi.org/10.1177/1077801212461428

Hill-Collins, P. (1990) Black Feminist Thought: Knowledge, Consciousness and the Politics of Empowerment, New York and London: Routledge

Holloway, I. (1997). Basic Concepts for Qualitative Research. Oxford: Blackwell Science Ltd. 
Home Office \& Foreign and Commonwealth Office (2018, March 16). Retrieved 22/8/2018 https://assets.publishing.service.gov.uk/government/uploads/system/uploads/attachme $\underline{\text { nt_data/file/730155/2017_FMU_statistics_FINAL.pdf }}$

Idriss, M (2017) Not domestic violence or cultural tradition: is honour-based violence distinct from domestic violence? Journal of Social Welfare and Family Law 39 (1) 3-21. https://doi.org/10.1080/09649069.2016.1272755

Kandiyoti, D. (1988). Bargaining with patriarchy. Gender \& Society, 2, 274-290. https://doi.org/10.1177/089124388002003004

Kelly, L. (2007). 'A conducive context': Trafficking of persons in Central Asia in M. Lee (Ed.) Human Trafficking (pp. 73.91) Cullompton: Willan Publishing.

Natcen (2009). Forced Marriage: Prevalence and Service Responses, retrieved from http://natcen.ac.uk/media/23519/forced-marriage-prevalence-service.pdf

Patton, M.Q. (1990). Qualitative Evaluation and Research Methods. (2 ${ }^{\text {nd }}$ edition), Newbury Park, CA: Sage.

Scottish Government (2011). Forced Marriage Statutory Guidance. Edinburgh: Scottish Government. Retrieved 23/08/2017, from: http://www.gov.scot/Resource/Doc/1124/0123428.pdf

Scottish Government (2014). Forced Marriage Statutory Guidance. (revised) Edinburgh: Scottish Government. Retrieved 23/08/2017 from: http://www.gov.scot/Resource/0046/00460509.pdf

Scottish Government (2017). Getting it Right for Every Child (GIRFEC) Edinburgh: Scottish Government. Retrieved 23/08/2017 from: http://www.gov.scot/Topics/People/Young-People/gettingitright 
Shankar, I., \& Northcott, H. (2009). Through my son: Immigrant women bargain with patriarchy. Women's Studies International Forum, 32, 424-434. https://doi.org/10.1016/j.wsif.2009.09.004

Stark, E. (2007). Coercive control: How men entrap women in personal life. Oxford: Oxford University Press.

Swan, S., Gambone, L. and Fields, A. (2005). An Empirical Examination of a Theory of Women's Use of Violence in Intimate Relationships. Technical report. Retrieved from https://www.ncjrs.gov/pdffiles1/nij/grants/208611.pdf.

Young Larance, L. \& Miler, S.L. (2017) In her own words: women describe their use of force resulting in court-ordered intervention, Violence Against Women, 23 (12), 1536-1559. https://doi.org/10.1177/1077801216662340

Yuval Davis, N. (1997). Gender and Nation. London: Sage Publications. 
Khatidja Chantler $(\mathrm{PhD})$ is Reader in Social Work at the Connect Centre for International Research on interpersonal violence, University of Central Lancashire. She is a senior researcher with an extensive track record and expertise on researching forced marriage and domestic abuse in minoritised communities. Khatidja has published numerous articles in national and international journals and is author of several book chapters and co-editor of three books. Her work is widely cited nationally and internationally. She also has expertise in qualitative research methods, gender, ethnicity, self-harm and violence against women in different contexts.

Melanie McCarry $(\mathrm{PhD})$ is joint Principle Investigator, and Research Lead, in the Equally Safe in Further and Higher Education project (tiny.cc/equallysafeHE) which is implementing the Scottish Government strategy on gender based violence in Further and Higher education contexts. Melanie is also the Programme Director for the BA Social Policy. Melanie has published widely on men's violence against women and children, and for over 20 years has worked collaboratively with colleagues in both academia and the feminist activist movement. She is currently developing the first MOOC (Massive Open Online Course) on Forced Marriage to be launched spring 2019. 